\title{
INDUSTRIAL ENGINEERING
}

DOI https://doi.org/10.30525/978-9934-26-046-9-19

\section{ІНВЕРСІЙНИЙ МЕТОД КЕРУВАННЯ НАДІЙНІСТЮ НА ЕТАПАХ ПРОЕКТУВАННЯ}

\author{
Алфьоров О. I. \\ доктор технічних наук, дочент, \\ професор кафедри експлуатайї, надійності, міиності \\ та будівництва імені В. Я. Аніловича \\ Савченко В. Б. \\ кандидат технічних наук, доцент, \\ доиент кафедри експлуатації, надійності, міиності \\ та будівництва імені В. Я. Аніловича

\section{Понаморенко В. В.} \\ аспірант кафедри експлуатаиії, надійності, міџності \\ та будівничтва імені В. Я. Аніловича \\ Харківський національний технічний університет \\ сільського господарства імені Петра Василенка \\ м. Харків, Украӥна
}

Особливу увагу слід приділяти раптовим механічним відмовам тому, що їх виникнення практично неможливо діагностувати і відповідно передбачати моменти відмов. Тому під час проектування необхідно таким чином обирати конструктивні і технологічні параметри, щоб вони забезпечували достатній рівень його безвідмовності, що гарантується впродовж заданого періоду експлуатації.

В роботах $[1,2]$ розроблені стохастичні моделі, використання яких дозволяє прогнозувати зміну імовірності безвідмовної роботи в залежності від наробітку у випадку раптових механічних відмов.

Перспективним напрямком удосконалення інженерного прогнозування та забезпечення механічної надійності $є$ використання інверсійного методу та інвертуємих стохастичних моделей надійності $[1,2]$. Статистичне оцінювання залежності імовірності безвідмовної роботи 
від наробітку у випадку механічних відмов зазвичай виконується за цензурованими вибірками даних [3, с. 11].

Отримано експлуатаційні данні щодо раптових відмов 13-ти культиваторів з пружними С-образними стійками. В усіх випадках руйнування стійок мав місце раптовий злам. Напрацювання агрегатів складало від однієї до сорока тисяч гектарів обробленої площі. Було зафіксовано 42 раптові відмови у 260 стійок: злам стійок. За час спостережень сумарний наробіток культиваторів склав більш ніж 280 тис. га.

Методологією статистичного аналізу інформації щодо надійності $\epsilon$ непараметричний метод аналізу [3, с. 11; 4] цензурованої вибірки, згрупованої по інтервалах, результати якої у вигляді імовірності безвідмовної роботи наведені на рис. 1 .

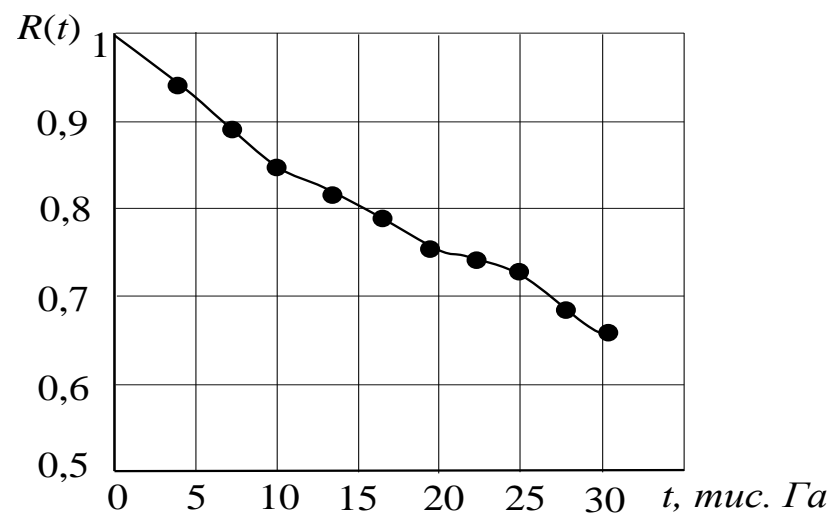

Рис. 1. Зміна імовірності безвідмовної роботи стійок в залежності від наробітку

Дані, отримані за результатами статистичного аналізу надійності пружних стійок дозволяють використати інверсійний метод керування надійністю. Побудова такої моделі дозволяє додатково використати теоретичну модель надійності у випадку раптових відмов [5].

В окремому випадку, якщо екстремальні навантаження і несуча здатність $є$ подібними випадковими величинами і розподілені за законом Вейбулла з одним і тим же коефіцієнтом варіації, то можна отримати аналітичний вираз для прогнозування ймовірності безвідмовної роботи залежно від напрацювання (Рис. 2) [1, с. 60; 2, с. 67]. 


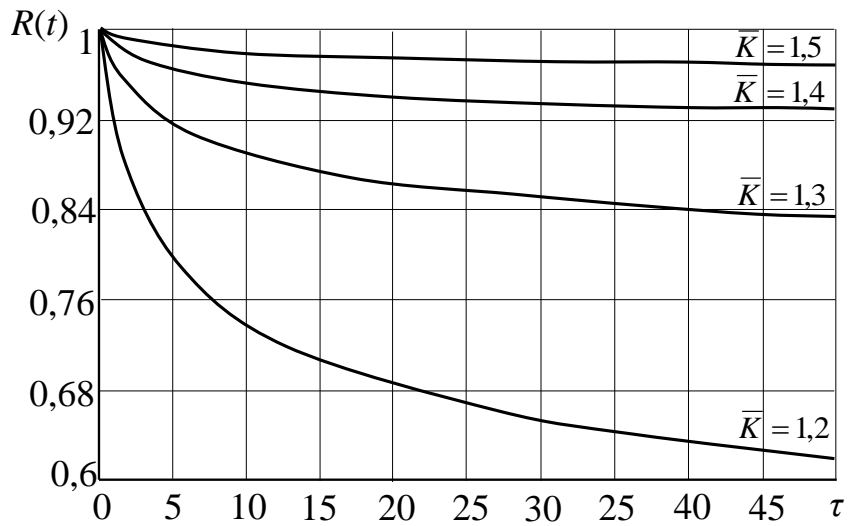

Рис. 2. Графіки кривих зміни ймовірності безвідмовної роботи в залежності від напрацювання і коефіціснту запасу

На рис. 2 показані графіки ймовірності безвідмовної роботи залежно від безрозмірного напрацювання і відповідають розподілу Вейбулла для навантаження і несучої здатності при коефіцієнті варіації навантаження і несучої здатності $\mathbf{V = 0 , 1}[1$, с. 63,2, с. 70$]$.

Відображаючи на графіку 2 у відповідних координатах емпіричну залежність ймовірності безвідмовної роботи пружної стійки культиватора $R_{i}$ (Рис. 1) можливо отримати значення параметрів навантажуваності, що відповідають імовірнісно обгрунтованому коефіцієнту запасу.

\section{Література:}

1. Grynchenko O., Alfyorov O. Mechanical Reliability. Prediction and Management Under Extreme Load Conditions. Springer Nature: Switzerland AG, 2020. 125 p. https://doi.org/10.1007/978-3-030-41564-8

2. Гринченко А.С., Алферов А.И. Основы прогнозирования и управления надежностью в условиях экстремальных нагрузок. Харків: ТОВ «Планета-Принт», 2017. 136 с.

3. Надійність машин: Практикум / О.С. Гринченко, В.Г. Кухтов, О.І. Алфьоров та ін., за заг. ред. О.С. Гринченка, В.Г. Кухтова. Харків: ТОВ «Планета-прінт», 2018. 140 с.

4. Алфьоров, О. І., Антощенков Р. В., Юр'єва Г. П. Експериментальне дослідження коливань робочих органів культиватора на пружній стійці. Machinery \& Energetics. Journal of Production Research. Kyiv. Ukraine. 2019. Vol. 9. № 2. P. 129-132. 
5. Гринченко А.С., Алферов А.И. Прогнозирование надежности элементов машин при случайном пуассоновском потоке экстремальных нагружений Науковий журнал «Технічний сервіс агропромислового, лісового та транспортного комплексів». 2017. № 7 С. 141-148.

DOI https://doi.org/10.30525/978-9934-26-046-9-20

\title{
ТЕХНІЧНЕ ДІАГНОСТУВАННЯ В СИСТЕМІ ТЕХНІЧНОЇ ЕКСПЛУАТАЦІЇ АВТОМОБІЛІВ
}

\author{
Блезнюк О. В. \\ кандидат технічних наук, дочент \\ Харківський начіональний технічний університет \\ сільського господарства імені Петра Василенка \\ Іванов B. I. \\ кандидат технічних наук, доцент \\ Харківський начіональний технічний університет \\ сільського господарства імені Петра Василенка \\ м. Харків, Украӥна
}

Існує нагальна проблема підвищення рівня технічної експлуатації автомобілів (TEA), що корелюється із їх технічним станом і надійністю. Одним з найважливіших показників, що впливають на якість системи TEA, є оперативність і якість виконуваних робіт, які визначаються кваліфікацією виконавців послуг та наявністю повної науковотехнічної документації [1]. Аналіз причинно-наслідкової схеми якості виконання робіт (рис. 1) показав, що дослідження першопричини дефекту необхідно вести за категорією «порушення технології працівниками».

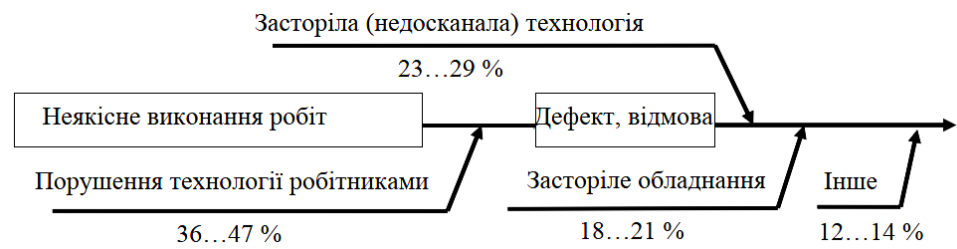

Рисунок 1. Причинно-наслідкова схема якості виконання робіт 